\title{
Epidemiology of work-related lower back pain among rehabilitation professionals in Saudi Arabia
}

Mostafa Abolfotouh, ${ }^{1,2}$ Fay Alomair, ${ }^{3}$ Dalal Alangari, ${ }^{2}$ Ibraheem Bushnak, ${ }^{1,2}$ Bader Aldebasi $1^{1,2}$ and Afaf Almansoof ${ }^{4}$

${ }^{1}$ King Abdullah International Medical Research Center, Ministry of National Guard -Health Affairs, Riyadh, Saudi Arabia (Correspondence to: M. Abolfotouh: mabolfotouh@gmail.com). ${ }^{2}$ King Saud bin-Abdulaziz University for Health Science, Ministry of National Guard - Health Affairs, Riyadh, Saudi Arabia. ${ }^{3}$ College of Medical Rehabilitation, Qassim University, Qassim, Saudi Arabia. ${ }^{4}$ King Abdulaziz Medical City, Ministry of National Guard Health Affairs, Riyadh, Saudi Arabia.

\begin{abstract}
Background: Occupational and physical therapists are at risk of musculoskeletal pain and injuries possibly due to their work-related activities, posture and affected body mechanics.

Aims: To investigate the epidemiology of lower back pain among rehabilitation professionals.

Methods: A cross-sectional survey of 259 physical and occupational therapists in rehabilitation centres in Saudi Arabia was conducted during July-August 2019, using the Modified Nordic Questionnaire. Data on different measures of lower back pain, and its consequences and risk factors were collected. Logistic regression analysis was done to identify significant predictors of lower back pain.

Results: Rehabilitation professionals experienced 73.7\% 1-year lower back pain prevalence, 52.5\% intense pain that lasted $\geq$ 1 day, $22.4 \%$ chronic lower back pain, $23.9 \%$ sick-leave-seeking lower back pain and $18.5 \%$ medical-care-seeking lower back pain. Difficult/impossible activities of daily living in standing up (45.5\%), employment (44.0\%), climbing stairs (33.9\%), walking $(33.0 \%)$, sitting $(29.3 \%)$, sleeping and travel $(29.8 \%$ each), awakening $(23.0 \%)$, social life $(26.2 \%)$, and personal care $(15.7 \%)$ were reported. Lower back pain was responsible for stopping work in $32.5 \%$ of participants, with a mean $1.38( \pm 2.96)$ days off work during the last year. One half of participants (50.3\%) were treated by physiotherapy, $25.1 \%$ by medical care, and $39.3 \%$ requested rest days and/or sick leave. Physical stress and $<10$ years' experience were significant predictors of lower back pain.
\end{abstract}

Conclusion: Prevalence of lower back pain was high among rehabilitation professionals, with a high impact on activities of daily living. Physiotherapy was the main management adopted. Educational programmes are necessary to teach proper use of body mechanics, and sports activity programmes to reduce the risk of lower back pain and arrange for proper rest periods.

Keywords: physical therapy, prevalence, ergonomics, consequences, occupational lower back pain.

Citation: Abolfotouh M; Alomair F; Alangari D; Bushnak I; Aldebasi B; Almansoof A. Epidemiology of work-related lower back pain among rehabilitation professionals in Saudi Arabia. East Mediterr Health J. 2021;27(4):390-398. https://doi.org/10.26719/emhj.21.019

Received: 07/04/20; accepted: 27/11/20

Copyright (C) World Health Organization (WHO) 2021. Open Access. Some rights reserved. This work is available under the CC BY-NC-SA 3.0 IGO license (https://creativecommons.org/licenses/by-nc-sa/3.o/igo)

\section{Introduction}

The World Health Organization defines work-related diseases as any disease that occurs as a consequence of exposure to multiple work-related risk factors and causes (1). Low back pain (LBP) is the most frequently reported work-related musculoskeletal disorder associated with physical demands of various professions (2). LBP is characterized by 1 or more of the following measures: pain that lasts for 1 year; daily pain for $\geq 3$ months; intense pain that lasts for 1 day; and pain that results in seeking medical care and/or sick leave $(3,4)$. Throughout the typical work day, patient care staff may find themselves ascending or descending stairs, bending, twisting, lifting heavy objects or transferring patients; all of which can contribute to the onset of LBP, especially if optimal body mechanics are not utilized. Physical work that requires poor posture and frequent lifting, bending or twisting is a risk factor for LBP (5). Work-related LBP often leads to disability and affects the activities of daily living (ADLs) such as mobility, dressing, sitting and standing (6).

Rehabilitation professionals, including physical therapists (PTs), occupational therapists (OTs), physical therapy assistants and certified OT assistants all may encounter some type of patient care that involves manual lifting or manoeuvring at some point throughout the typical work day. OTs and PTs both receive training in their respected professional courses in proper body mechanics and self-protection while handling and transferring patients (7). However, despite this training, these professionals are still at risk for musculoskeletal injuries associated with patient handling. PTs and OTs are responsible for treating patients who have various types of pain. Higher levels of work-related LBP could be due to extreme loads in the work setting or faulty musculoskeletal techniques used in treating patients. Therapists may overload their muscles and joints during treatment sessions, which increases the risk of $\operatorname{LBP}(7,8)$. These injuries are due to patient transferring, ambulation, 
repositioning, and related repetitive tasks that are often done in an irregular body position, unconsciously, and can lead to LBP (9).

In a recent systematic review and meta-analysis in Saudi Arabia, pooled prevalence rates of LBP of $40.8 \%$, $65.0 \%$ and $81.4 \%$ were obtained for week, year and career, respectively, across all professional groups (10). Nurses and PTs were more susceptible to LBP than the other professions were; age, body mass index, and female gender were the most commonly reported individual risk factors; and work-related activities requiring back bending and twisting, lifting and pulling objects, and manual patient handling were the main occupational risk factors.

However, evidence of LBP in rehabilitation staff is limited, and even conflicting in the current literature (1). Therefore, further research is needed to expand research on the prevalence and severity of LBP and its impact on ADLs among rehabilitation staff. The aim of this study was to investigate work-related LBP among PTs and OTs in Saudi Arabia by estimation of the prevalence of workrelated LBP, determination of its predictors, its personal and occupational consequences, and the different management methods adopted for it.

\section{Methods}

\section{Study population}

All registered members of the Saudi Physical Therapy Association (SPTA) and Saudi Occupational Therapy Association (SOTA) were invited to complete an online electronic questionnaire. Pregnant women and individuals with LBP caused by injuries or birth defects were excluded.

\section{Sample size and sampling techniques}

Based on a prevalence of $68 \%$ of LBP among rehabilitation professionals in a previous study (8), and by using Raosoft sample size calculator, with a confidence level of $95 \%$ and a margin of error of $5 \%$, the estimated sample size was 274 rehabilitation professionals. The sample size required was 329 participants after accounting for nonresponses or incomplete data. A convenience sampling technique was used to select the participants. All potential participants $(\sim 1200)$ were invited to participate via SOTA and SPTA social media channels (Email, Twitter, Instagram and Facebook), with a link to the data collection tool. They were reminded to participate within 2 weeks from the first invitation date. A total of 259 completed questionnaires were analysed (response rate $22 \%$ ).

\section{Data collection}

The previously validated Modified Nordic Questionnaire was constructed in a survey monkey that limits 1-time participation per unique IP address, and distributed via social media to the potential participants $(3,4,11,12)$. It was structured into 4 sections. (1) Demographic characteristics: age, sex, height, weight and comorbidity such as diabetes, hypertension and arthritis. (2) Lifestyle informa- tion: rehabilitation professionals' lifestyle and behaviour such as exercise (walking and running, for 15 minutes/ day) and smoking habits. (3) Occupational characteristics: nature of the participants' rehabilitation tasks, such as lifting of heavy objects and/or patients, work load and, sick leave due to LBP. (4) Work-related LBP: LBP within the last year, using the modified Nordic Questionnaire (3), LBP impact on work and ADLs, sick leave because of LBP, and manageability of pain. Definitions of LBP were according to different measures/characteristics adopted from previous studies $(3,4,11,12)$. Reliability of the questionnaire was assessed in terms of internal consistency. Cronbach's was calculated, and a coefficient of 0.81 was considered adequate.

\section{Ethics approval and consent to participate}

This research was approved by the Institutional Review Board (IRB) of The Ministry of National Guard-Health Affairs, Riyadh, Saudi Arabia (Ref. RSS19/040/R). Each participant was provided a research information/consent form. The researchers invited the rehabilitation professionals, via their corresponding societies, to take part in the study. The purpose of the study and how to fill in the questionnaire were explained, and all issues regarding confidentiality and privacy were assured and protected at all times. No written consent was sought, as there were no personal identifiers on the questionnaires, and this was approved by the IRB. Submission of responses to the questionnaire was considered to constitute implied consent. The voluntary nature of participating in the survey was made explicit and unambiguous in the cover letter.

\section{Data analysis}

SPSS version 25 was used for data entry and analysis. Descriptive statistics such as frequency and percentages, mean score and standard deviation of all independent variables were used. Statistical analysis was used to test associations of the LBP prevalence and rehabilitation professionals' personal and work-related characteristics. The $\chi^{2}$ test and Fisher's exact test were used for qualitative variables and Student's t test for quantitative variables. Bivariate analysis was used to examine relationships between LBP and possible risk factors. Multiple logistic regression analysis was applied to identify the significant predictors of LBP, with the following variables as independent variables; gender, age group $(<30$ and $\geq 30$ years), running practice (yes or no), direct patient contact (yes or no), duration of experience in current work $(<10$ and $\geq 10$ years), duration of shift (6-9 or $10-12 \mathrm{~h}$ ) and physical stress (yes or no). $P \leq 0.05$ was considered statistically significant.

\section{Results}

\section{Demographic characteristics}

The personal characteristics of 196 PTs and 63 OTs are shown in Table 1. Most of them were single (61.4\%), with a mean age of 29.27 (7.04) years and mean work duration 


\begin{tabular}{|c|c|c|}
\hline Characteristics & $n=259$ & $\% /$ ratio \\
\hline Male/female ratio & 109/150 & 1:1.4 \\
\hline Marital status (single/married ratio) & $159 / 100$ & 1:1.6 \\
\hline Diabetes & 10 & $3.9 \%$ \\
\hline Arthritis & 1 & $0.4 \%$ \\
\hline Trauma/fracture of spine, pelvis, legs & 17 & $6.6 \%$ \\
\hline Spinal problems (e.g., scoliosis) & 19 & $7.3 \%$ \\
\hline \multirow[t]{2}{*}{ Back surgery } & 3 & $1.2 \%$ \\
\hline & Mean & SD \\
\hline Age (21-63 yr) & 29.27 & 7.04 \\
\hline $\begin{array}{l}\text { Duration of employment in current job } \\
(1-32 \text { yr) }\end{array}$ & 5.79 & 5.27 \\
\hline Working days in 1 week & 2.39 & 0.71 \\
\hline Weight (37-128 kg) & 70.42 & 16.47 \\
\hline Height $(136-188 \mathrm{~cm}) 164.77$ & 10.33 & \\
\hline BMI $\left(14.82-44.06 \mathrm{~kg} / \mathrm{m}^{2}\right)$ & 25.66 & 4.98 \\
\hline Lifestyle behaviour & $n$ & $\%$ \\
\hline Walking $>15 \mathrm{~min} / \mathrm{d}$ & 185 & 71.4 \\
\hline Running $>15 \mathrm{~min} / \mathrm{d}$ & 41 & 15.8 \\
\hline Others $>15 \mathrm{~min} / \mathrm{d}$ & 98 & 37.8 \\
\hline Smoking & 40 & 15.4 \\
\hline
\end{tabular}

$B M I=$ body mass index $; S D=$ standard deviation .

of 5.8 (5.3) years. Their mean body mass index was 25.7 (5.0) $\mathrm{kg} / \mathrm{m}^{2}$. Most participants $(71.4 \%)$ practiced walking for $>15$ minutes/day but only $15.8 \%$ practiced running for $>15$ minutes/day, and $15.4 \%$ were smokers.

\section{Work-related characteristics}

Most participants (92.3\%) were in direct contact with patients, and office work was the nature of the work for only $7.7 \%$ of participants (Table 2). Only $14.3 \%$ of participants undertook shift work, while the majority undertook day work (85.7\%). Shifts of 6-9 hours were reported by $96.1 \%$ of participants, with only $3.9 \%$ reporting shifts of 10-12 hours duration shift.

\section{Prevalence of lower back pain}

LBP during the past year that lasted at least 1 day was prevalent among $73.7 \%$ of participants and intense pain that lasted at least 1 day (score $>6$ ) was prevalent among $52.5 \%$ (Table 3). Chronic LBP pain (22.4\%), sick-leave-seeking LBP $(23.9 \%)$ and treatment-seeking pain $(18.5 \%)$ were also reported. Days of sick leave due to LBP ranged from 0 to 30 days per participant during the past year, with an average of 1.38 (2.96) days, and the average number of days/month with LBP was 4.89 (6.32).

\section{Consequences of lower back pain}

Among the 191 participants with LBP in the past year, the following ADLs were reported as difficult or impossible: climbing stairs $(33.9 \%)$, sitting $(29.3 \%)$, walking $(33.0 \%)$, standing up (45.5\%), sleeping (29.8\%), getting out of bed
$(23.0 \%)$, social life $(26.2 \%)$, travel $(29.8 \%)$, employment (44.0\%) and personal care (15.7\%) (Table 3). Physiotherapy was the main management modality adopted (50.3\%), followed by medical care (25.1\%). Seeking sick leave and/or rest days was reported by $39.3 \%$ of participants with LBP. Nearly one third (32.5\%) of participants reported stopping work in the past year because of LBP, with a mean of 1.38 (2.96) days.

\section{Factors associated with lower back pain}

Table 4 shows that age $>30$ years was significantly associated with LBP $(P=0.013)$. The practice of running for $>$ 15 minutes/day was a protective factor against LBP $(P=$ 0.043). Less than 10 years' experience $(P<0.001)$, direct contact with patients $(P=0.047)$, enrolment in 6-9-hour shifts $(P=0.013)$, and exposure to physical stress $(P=$ 0.005 ) were all significantly associated with LBP. However, after adjustment for all potential variables, $<10$ years' experience in the current job $(P=0.034)$ and exposure to physical stress $(P<0.001)$ were the only significant predictors of LBP (Table 5).

\section{Discussion}

In the present study of rehabilitation professionals in Saudi Arabia, most participants (73.7\%) reported having LBP for at least 1 day in the past year, which was similar to some previous studies (11,13-15), but higher than in others (16-18). These differences in LBP prevalence rates could be explained by the difference in methodology and definition of LBP adopted (3). In the present study, the preva-

\section{Table 2 Work characteristics}

\begin{tabular}{|lcc|}
\hline Work nature & $\mathbf{n}$ & $\%$ \\
\hline Direct contact with patients & 239 & 92.3 \\
Office work & 20 & 7.7 \\
\hline Shift nature & & \\
$\quad$ Day work & 222 & 85.7 \\
$\quad$ Shift work & 37 & 14.3 \\
\hline Shift hours & & \\
$\quad$ 6-9/shift & 249 & 96.1 \\
$\quad$ 10-12shift & 10 & 3.9 \\
Work days/week & $5.2(0.6)$ & \\
Work experience & & \\
$\quad \leq 10$ yr & 215 & 83.0 \\
$\quad>10$ yr & 44 & 17.0 \\
\hline Intensity of workload & & \\
\hline$\quad$ Light/moderate & 163 & 62.9 \\
$\quad$ Heavy/overwhelming & 96 & 37.1 \\
\hline Type of workloada & $\mathbf{n}$ & $\%$ \\
\hline $\begin{array}{l}\text { Physical stress } \\
\text { Sitting > 4 h/shift }\end{array}$ & 179 & 69.1 \\
Standing/moving > 4 h/shift & 16 & 6.2 \\
\hline
\end{tabular}

${ }^{a}$ Categories are not mutually exclusive. 


\begin{tabular}{|c|c|c|}
\hline Measures of prevalence $(n=259)^{a}$ & $\mathbf{n}$ & $\%$ \\
\hline LBP in past $12 \mathrm{mo}$ & 191 & 73.7 \\
\hline Chronic LBP daily for $\geq 3 \mathrm{mo}$ & 58 & 22.4 \\
\hline Intense pain that lasted $\geq 1 \mathrm{~d}$ & 136 & 52.5 \\
\hline Medical-care-seeking LBP & 48 & 18.5 \\
\hline Sick-leave-seeking LBP & 62 & 23.9 \\
\hline Intensity of LBP $(n=191)^{b}$ & $n$ & $\%$ \\
\hline Mild & 75 & 39.3 \\
\hline Moderate & 95 & 49.7 \\
\hline Severe/intense & 21 & 11.0 \\
\hline Sickness absence for LBP $(n=191)$ & $n$ & $\%$ \\
\hline None & 129 & 67.5 \\
\hline $1-6 d$ & 50 & 26.2 \\
\hline $1-2$ wk & 12 & 6.3 \\
\hline Mean (SD) (d) & $1.38(2.96)$ & \\
\hline Difficult/impossible ADL $(n=191)^{\mathrm{a}}$ & $n$ & $\%$ \\
\hline Getting out of bed & 44 & 23.0 \\
\hline Sleeping & 57 & 29.8 \\
\hline Sitting & 56 & 29.3 \\
\hline Standing up & 87 & 45.5 \\
\hline Walking & 63 & 33.0 \\
\hline Climbing stairs & 61 & 33.9 \\
\hline Personal care & 30 & 15.7 \\
\hline Social life & 50 & 26.2 \\
\hline Travel & 57 & 29.8 \\
\hline Employment & 84 & 44.0 \\
\hline Overall & 76 & 39.8 \\
\hline How was LBP managed $(n=191)^{a}$ & $n$ & $\%$ \\
\hline Medication & 48 & 25.1 \\
\hline Rest day/sick leave & 75 & 39.3 \\
\hline Physiotherapy & 96 & 50.3 \\
\hline Others & 30 & 15.7 \\
\hline
\end{tabular}

${ }^{a}$ Categories are not mutually exclusive.

${ }^{b}$ Based on respondent self-reports.

$A D L=$ activity of daily living; $L B P=$ lower back pain

lence rates were: chronic LBP (22.4\%), intense LBP (52.5\%), medical-care-seeking LBP (18.5\%), and sick-leave-seeking LBP (23.9\%). LBP has a high prevalence among healthcare providers and has serious medical and professional consequences (19). Stopping work due to LBP is considered to be the main indicator for evaluation of the professional consequences of LBP. In the present study, LBP was not the main reason for seeking sick leave as most rehabilitation professionals were on leave for $<1$ week because of it. The rate of sick leave of $32.5 \%$ due to LBP in our survey was similar to that in other studies $(3,20)$. In our study, the mean duration of stopping work was 1.38 days/year, which is lower than 4.5 and 15 days reported by nurses $(3,20,21)$. Disability due to chronic LBP varied between $11 \%$ and $76 \%(22,23)$. In our study, more than one third of all rehabilitation professionals with LBP reported limitation in 1 or more of the following ADLs: sleeping, getting out of bed, standing up, walking, sitting, climbing stairs, travel, employment and personal care. Our study showed that the magnitude of the effect of LBP was profound while the level of experienced LBP was mostly minimal and moderate. One of the possible reasons for this was the fact that the questionnaire did not attach the clear/ operational definition of a number of asked variables, so the response was subjected to response bias. Due to the potential bias, the outcomes of this study may give an impression that working in rehabilitation activities is hazardous. Variation in rates of disability in different studies could be attributed to the different methods used in the measurement of disability.

Heavy workload was reported by most of the rehabilitation professionals in our study in terms of heavy objects/physical assistance and physical stress. Physical stress was associated with higher prevalence of LBP, and participants with physical stress were nearly 4 times more likely to contract LBP than those with no physical stress. This finding was in agreement with other studies $(3,20,24)$. Length of work experience was a significant protector against LBP, with participants with $<10$ years' experience being 3 times more likely to contract LBP than those with $\geq 10$ years. Previous studies have shown that with experience, healthcare workers learn how to protect their backs and become more familiar with how to deal with heavy objects without hurting their backs $(25,26)$. Other work-related factors such as shift hours and shift nature, did not show significant associations with LBP prevalence. However, it is difficult to separate the staff's risk factors from the work-related risk factors (3).

In agreement with previous studies $(3,24)$, we found that the practice of running for $>15$ minutes/day by rehabilitation professionals was a protective factor against LBP. However, after adjusting for different confounders, this association was not seen. Association between LBP and some sociodemographic and personal characteristics of healthcare providers such as age (3), gender $(3,25,26)$, marital status (3), obesity $(3,12,24,27,28)$, smoking $(3,25,29)$ and comorbidity, such as arthritis, diabetes or spinal problems, have been investigated. However, none of these factors was a predictor of LBP among rehabilitation professionals in our study.

Lower back pain is managed by medication, physiotherapy or surgical intervention (25). In the present study, physiotherapy was used in $50.3 \%$ of the cases, as compared to only $11.5 \%$ in a previous study on nurses (20). This finding might reflect the fact that rehabilitation professionals are more convinced of the effect of physiotherapy in relieving LBP than other treatment modalities, such as drug treatment, which was adopted by only $25.1 \%$ of LBP sufferers in our study. Rehabilitation professionals are supposed to have more easy access to physiotherapy than other healthcare workers have. 


\begin{tabular}{|c|c|c|c|c|c|}
\hline Sociodemographics & $\mathbf{n}$ & $\%$ & $\chi^{2}$ & $\boldsymbol{P}$ & OR $(95 \% \mathrm{CI})$ \\
\hline \multicolumn{6}{|l|}{ Sex } \\
\hline Male & 74 & 67.9 & \multirow[t]{2}{*}{3.33} & \multirow[t]{2}{*}{0.07} & \multirow[t]{2}{*}{$1.68(0.97-2.93)$} \\
\hline Female & 117 & 78.0 & & & \\
\hline \multicolumn{6}{|l|}{ Age } \\
\hline$\leq 30 \mathrm{yr}$ & 53 & 63.9 & \multirow[t]{2}{*}{6.17} & \multirow[t]{2}{*}{$0.013^{*}$} & \multirow[t]{2}{*}{$2.06(1.16-3.65)$} \\
\hline$>30 \mathrm{yr}$ & 138 & 78.4 & & & \\
\hline \multicolumn{6}{|l|}{ Marital status } \\
\hline Single & 119 & 74.8 & \multirow[t]{2}{*}{0.26} & \multirow[t]{2}{*}{0.61} & \multirow[t]{2}{*}{$1.16(0.66-2.04)$} \\
\hline Married & 72 & 72.0 & & & \\
\hline Comorbidity & $n$ & $\%$ & $\chi^{2}$ & $\boldsymbol{P}$ & OR $(95 \% \mathrm{CI})$ \\
\hline \multicolumn{6}{|l|}{ Obesity } \\
\hline Yes & 97 & 78.2 & \multirow[t]{2}{*}{1.76} & \multirow[t]{2}{*}{0.19} & \multirow[t]{2}{*}{$1.47(0.83-2.59)$} \\
\hline No & 93 & 71.0 & & & \\
\hline \multicolumn{6}{|l|}{ Diabetes } \\
\hline Yes & 8 & 80.0 & \multirow[t]{2}{*}{2.10} & \multirow[t]{2}{*}{0.65} & \multirow[t]{2}{*}{$1.44(0.30-6.97)$} \\
\hline No & 183 & 73.5 & & & \\
\hline \multicolumn{6}{|l|}{ Arthritis } \\
\hline Yes & 1 & 100.0 & \multirow[t]{2}{*}{ FET } & 1.0 & - \\
\hline No & 190 & 73.6 & & & \\
\hline Spinal problem & & & & & \\
\hline Yes & 32 & 84.2 & 2.52 & 0.11 & $2.08(0.83-5.22)$ \\
\hline No & 159 & 71.9 & & & \\
\hline Lifestyle & $n$ & $\%$ & $\chi^{2}$ & $\mathbf{P}$ & OR $(95 \% \mathrm{CI})$ \\
\hline Wallking $>15 \mathrm{~min} / \mathrm{d}$ & & & & & \\
\hline Yes & 133 & 71.9 & 1.15 & 0.28 & $1.42(0.75-2.69)$ \\
\hline No & 58 & 78.4 & & & \\
\hline Running $>15 \mathrm{~min} / \mathrm{d}$ & & & & & \\
\hline Yes & 25 & 61.0 & 4.10 & $0.043^{*}$ & $0.49(0.24-0.99)$ \\
\hline No & 166 & 76.1 & & & \\
\hline Other sports $>15 \mathrm{~min} / \mathrm{d}$ & & & & & \\
\hline Yes & 67 & 68.4 & 2.36 & 0.13 & $1.55(0.88-2.72)$ \\
\hline No & 124 & 77.0 & & & \\
\hline Smolking & & & & & \\
\hline Yes & 30 & 75.0 & 0.04 & 0.84 & $0.93(0.43-2.01)$ \\
\hline No & 161 & 73.5 & & & \\
\hline Work-related characteristic & n & $\%$ & $\chi^{2}$ & $\mathbf{P}$ & OR $(95 \% \mathrm{CI})$ \\
\hline Work nature & & & & & \\
\hline Direct contact & 180 & $75 \cdot 3$ & 3.93 & $0.047^{*}$ & $2.50(1.11-6.32)$ \\
\hline Office & 11 & 55.0 & & & \\
\hline Shift duration & & & & & \\
\hline $6-9 h$ & 187 & 75.1 & 6.12 & $0.013^{*}$ & $4.52(1.24-16.56)$ \\
\hline $10-12 \mathrm{~h}$ & 4 & 40.0 & & & \\
\hline Shift nature & & & & & \\
\hline Day work & 165 & 74.3 & 0.27 & 0.60 & $0.82(0.38-1.76)$ \\
\hline Shift work & 26 & 70.3 & & & \\
\hline Heavy objects & & & & & \\
\hline Yes & 106 & 57.6 & 2.891 & 0.089 & $1.61(0.93-2.81)$ \\
\hline No & 32 & 45.7 & & & \\
\hline
\end{tabular}




\begin{tabular}{|c|c|c|c|c|c|}
\hline Work-related characteristic & n & $\%$ & $\chi^{2}$ & $\mathbf{P}$ & OR $(95 \% \mathrm{CI})$ \\
\hline \multicolumn{6}{|l|}{ Workload } \\
\hline Light/moderate & 133 & 75.1 & \multirow[t]{2}{*}{0.56} & \multirow[t]{2}{*}{0.45} & \multirow[t]{2}{*}{$1.25(0.70-2.25)$} \\
\hline Heavy overwhelming & 58 & 70.7 & & & \\
\hline \multicolumn{6}{|l|}{ Sitting hours } \\
\hline$>4$ & 12 & 75.0 & \multirow[t]{2}{*}{0.014} & \multirow[t]{2}{*}{0.91} & \multirow[t]{2}{*}{$1.07(0.33-3.45)$} \\
\hline$<4$ & 179 & 73.7 & & & \\
\hline \multicolumn{6}{|l|}{ Standing hours } \\
\hline$>4$ & 108 & 77.1 & \multirow[t]{2}{*}{1.82} & \multirow[t]{2}{*}{0.18} & \multirow[t]{2}{*}{$1.46(0.84-2.55)$} \\
\hline$<4$ & 83 & 69.7 & & & \\
\hline \multicolumn{6}{|l|}{ Physical stress } \\
\hline Yes & 147 & 82.1 & \multirow[t]{2}{*}{21.01} & \multirow[t]{2}{*}{$0.005^{*}$} & \multirow[t]{2}{*}{$3.76(2.10-6.74)$} \\
\hline No & 44 & 55.0 & & & \\
\hline \multicolumn{6}{|l|}{ Working days/week } \\
\hline $3-5$ & 143 & 75.7 & \multirow[t]{2}{*}{1.33} & \multirow[t]{2}{*}{0.25} & \multirow[t]{2}{*}{$0.70(0.38-1.28)$} \\
\hline$>5$ & 48 & 68.6 & & & \\
\hline \multicolumn{6}{|l|}{ Experience } \\
\hline$\geq 10 \mathrm{yr}$ & 23 & 52.3 & \multirow[t]{2}{*}{12.62} & \multirow[t]{2}{*}{$<0.001^{*}$} & \multirow[t]{2}{*}{$3.26(1.66-6.41)$} \\
\hline$<10 \mathrm{yr}$ & 168 & 78.1 & & & \\
\hline
\end{tabular}

This study had some limitations. The study had a cross-sectional design; therefore, causal associations between LBP and individual/lifestyle and professional factors were not guaranteed. This was a retrospective study using a questionnaire, thus there may have been recall bias. The Modified Nordic Questionnaire used in this study did not attach operational or clear definitions for many available items or answers, so there could have been response bias. The study sample was not representative of all rehabilitation professionals in the study setting, thus the study might have been subject to selection bias. However, while the numbers are not representative, they provide baseline and important results that show that problems do occur in this population, which warrant further investigation. The fact that only 259 of 274 participants responded to the survey, due to the limited time allocated for this study that was part of a prescheduled summer training for university students, may have affected the power of the study, with a shift of the predetermined level of precision of 0.05 to 0.06. Nevertheless, this was the first study in Saudi Arabia to investigate this group of rehabilitation professionals in a comprehensive survey about LBP and its individual and professional consequences.

\section{Conclusion}

Lower back pain is prevalent among rehabilitation professionals. Both personal and professional risk factors found in our survey are in accordance with those in the literature. LBP was not the main reason for sick leave. Physiotherapy was the main management modality adopted. Physical stress and $<10$ years' experience were

\begin{tabular}{lccccc}
\hline Table 5 Significant predictors of low back pain among rehabilitation professionals & & & \\
Independent variables & $\beta$ & SE & $\mathbf{P}$ & OR & $\mathbf{9 5 \%}$ CI \\
Age $(<30$ yr $=1$ ) & -0.11 & 0.44 & 0.81 & 0.90 & $0.38-2.12$ \\
Running (yes = 1) & -0.68 & 0.39 & 0.08 & 0.51 & $0.24-1.08$ \\
Direct patient contact (yes = 1) & 0.24 & 0.55 & 0.66 & 1.27 & $0.43-3.72$ \\
Experience $(<10$ yr = 1) & 1.08 & 0.51 & $0.034^{*}$ & 2.94 & $1.08-7.95$ \\
Duration of shift (6-9 h = 1) & 1.16 & 0.73 & 0.11 & 3.19 & $0.76-13.32$ \\
Physical stress (yes = 1) & 1.31 & 0.31 & $<0.001^{*}$ & 3.72 & $2.02-6.86$ \\
Constant & -1.79 & 0.82 & 0.03 & 0.17 & \\
\hline
\end{tabular}

"Statistically significant.

$\mathrm{CI}=$ confidence interval; $\mathrm{OR}=$ odds ratio; $S E=$ standard error. 
significant predictors that may be difficult to avoid. As a result, it may be beneficial for hospital administrators to adopt certain strategies, such as shorter shifts, sports programmes emphasizing physical activity practices and improved ergonomics and psychological health in their workplace. Conducting periodic assessments on rehabilitation professionals may be necessary for early detection of LBP. Future studies are needed to evaluate the most effective methods for LBP prevention.

\section{Acknowledgement}

This study was fully supported by King Abdullah International Research Center (KAIMRC), Riyadh, Saudi Arabia.

Funding: None.

Competing interests: None declared.

\section{Épidémiologie des douleurs lombaires liées au travail parmi les professionnels de la réadaptation en Arabie saoudite}

\section{Résumé}

Contexte: Les ergothérapeutes et les physiothérapeutes sont à risque de douleurs et de traumatismes musculosquelettiques pouvant être liés à leurs activités professionnelles, à leur posture et à leur mécanique corporelle affectée.

Objectifs : Étudier l'épidémiologie de la lombalgie chez les professionnels de la réadaptation.

Méthodes: Une enquête transversale a été menée auprès de 259 physiothérapeutes et ergothérapeutes dans des centres de réadaptation en Arabie saoudite entre juillet et août 2019, à l'aide du questionnaire nordique modifié. Des données ont été recueillies sur différentes mesures de la lombalgie, ses conséquences et ses facteurs de risque. Une analyse de régression logistique a été réalisée pour identifier les facteurs prédictifs significatifs de la lombalgie.

Résultats: Les professionnels de la réadaptation ont souffert de lombalgie au moins une fois durant l'année précédant l'étude pour 73,7\%; 52,5\% d'entre eux ont connu une douleur intense ayant duré un jour ou davantage, $22,4 \%$ ont souffert de lombalgie chronique, 23,9\% de lombalgie ayant occasionné un congé de maladie et 18,5\% de lombalgie ayant nécessité le recours à des soins médicaux. Les activités difficiles/impossibles de la vie quotidienne en posture debout (45,5\%), durant l'emploi (44,0\%), la montée des escaliers $(33,9 \%)$, la marche $(33,0 \%)$, la position assise $(29,3 \%)$, le sommeil et les voyages $(29,8 \%$ chacun), le réveil $(23,0 \%)$, la vie sociale $(26,2 \%)$ et les soins personnels $(15,7 \%)$ ont été signalées. La lombalgie a occasionné un arrêt de travail chez 32,5\% des participants, pour 1,38 jour $( \pm 2,96)$ au cours de la dernière année. La moitié des participants $(50,3 \%)$ ont été traités par kinésithérapie, $25,1 \%$ par soins médicaux et $39,3 \%$ ont demandé des jours de repos et/ou des congés de maladie. Le stress physique et le fait d'avoir moins de 10 ans d'expérience étaient des facteurs prédictifs significatifs de la lombalgie.

Conclusion : La prévalence de la lombalgie était élevée chez les professionnels de la réadaptation, avec un impact important sur les activités de la vie quotidienne. La physiothérapie était la principale prise en charge adoptée. Des programmes éducatifs sont nécessaires pour enseigner la bonne utilisation de la mécanique corporelle et des programmes d'activités sportives pour réduire le risque de lombalgie et prévoir des périodes de pause appropriées.

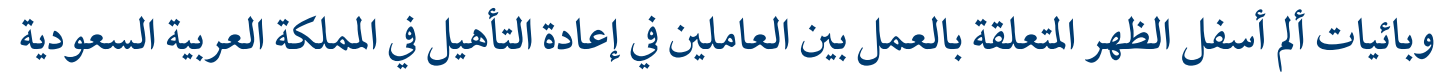

$$
\begin{aligned}
& \text { مصطفى أبو الفتوح، فاي العُمير، دلال العنقري، إبراهيم بوشناق، بدر الدباسي، عفاف المنصوف } \\
& \text { الخال|صة } \\
& \text { الخلفية: اختصاصيو العلاج المهني و الطبيعي مُعرَّضون للآلام والإصابات العضلية الهيكلية، وقد يرجع ذلك إلى الأنشطة المتعلقة بعملهم ووضعية }
\end{aligned}
$$

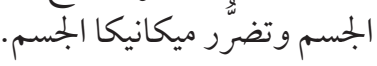

$$
\begin{aligned}
& \text { الأهداف: هدفت هذه الدراسة إلى تقصي السمات الوبائية لآلام أسفل الظهر بين العاملين في إعادة التأهيل. }
\end{aligned}
$$

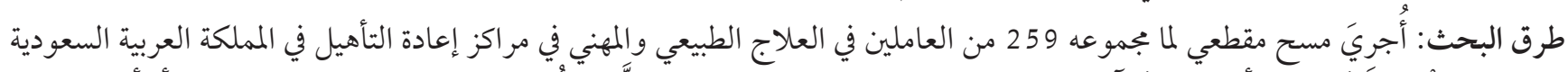

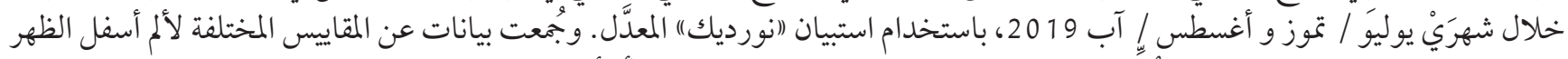

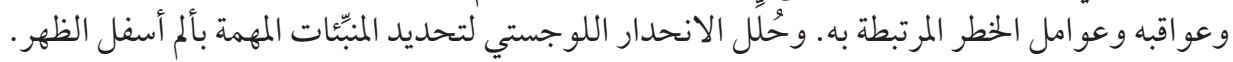




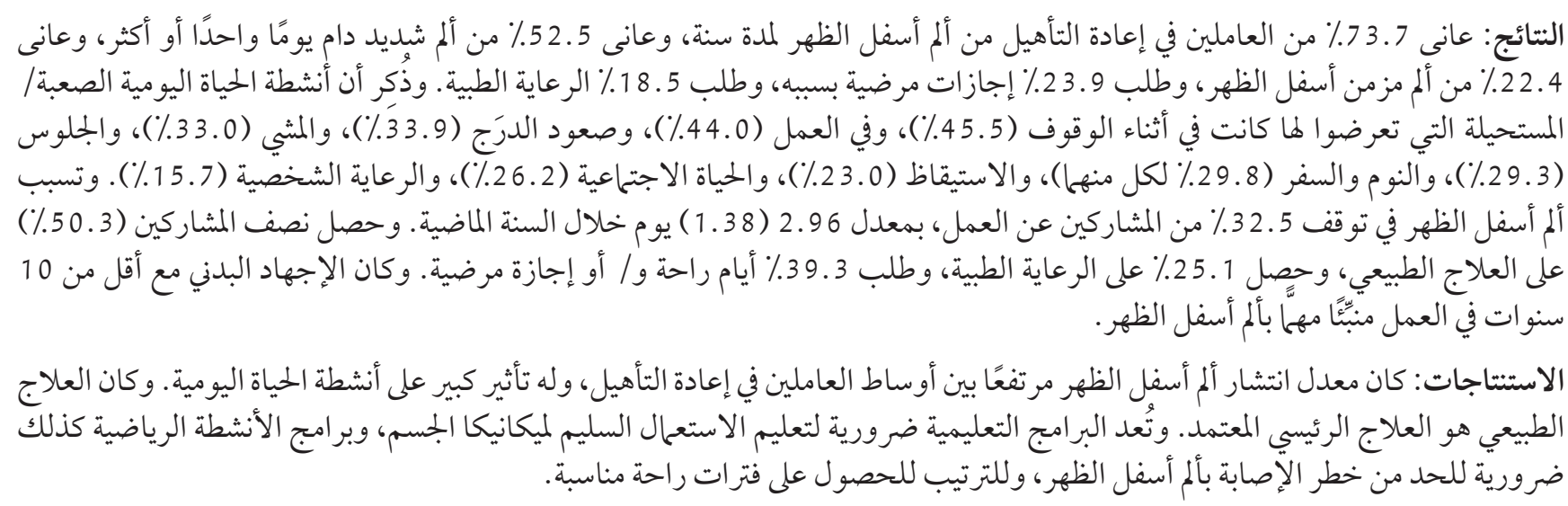

\section{References}

1. Occupational and work-related diseases [website]. Geneva: World Health Organization (https://www.who.int/occupational_ health/activities/occupational_work_diseases/en/_accessed 9 March 2021).

2. Omokhodion FO, Sanya AO. Risk factors for low back pain among office workers in Ibadan, Southwest Nigeria. Occup Med. 2003 Jun; 53(4):287-9. https://doi.org/10.1093/occmed/kqg063 PMID:12815127

3. Bejia I, Younes M, Jamila HB, Khalfallah T, Salem KB, Touzi M, et al. Prevalence and factors associated to low back pain among hospital staff. Joint Bone Spine. 2005 May;72(3):254-9. https://doi.org/10.1016/j.jbspin.2004.06.001 PMID:15850998

4. Violante FS, Fiori M, Fiorentini C, Risi A, Garagnani G, Bonfiglioli R, et al. Associations of psychosocial and individual factors with three different categories of back disorder. J Occup Health. 2004 Mar;46(2):100-8. https://doi.org/10.1539/joh.46.100 PMID:15090684

5. Coenen P, Kingma I, Boot CR, Twisk JW, Bongers PM, van Dieen JH. Cumulative low back load at work as a risk factor of low back pain: a prospective cohort study. J Occup Rehabil. 2013 Mar;23(1):11-8. https://doi.org/10.1007/s10926-012-9375-z PMID:22718286

6. Andersson GB. Epidemiological features of chronic low-back pain. Lancet. 1999 Aug 14;354(9178):581-5. https://doi.org/10.1016/ So140-6736(99)01312-4 PMID:10470716

7. Darragh A, Huddleston W, King P. Work-related musculoskeletal injuries and disorders among occupational and physical therapists. Am J Occup Ther. 2009 May-Jun;63(3):351-62. https://doi.org/10.5014/ajot.63.3.351 PMID:19522144

8. Islam M, Habib M, Hafez M, Nahar N, Lindstrom-Hazel D, Rahman M. Musculoskeletal complaints among physiotherapy and occupational therapy rehabilitation professionals in Bangladesh. Work. 2015;50(3):379-86. https://doi.org/10.3233/WOR-151994 PMID:25672956

9. Passier L, McPhail S. Work related musculoskeletal disorders amongst therapists in physically demanding roles: qualitative analysis of risk factors and strategies for prevention. BMC Musculoskelet Disord. 2011 Jan 25;12:24. https://doi.org/10.1186/14712474-12-24 PMID:21266039

10. Al Amer HS. Low back pain prevalence and risk factors among health workers in Saudi Arabia: a systematic review and meta-analysis. J Occup Health. 2020 Jan;62(1):e12155. https://doi.org/10.1002/1348-9585.12155 PMID:32710807

11. Josephson M, Lagerstrom M, Hagberg M, Hjelm WE. Musculoskeletal symptoms and job strain among nursing personnel: a study over a three year period. Occup Environ Med. 1997 Sep;54(9):681-5. https://doi.org/10.1136/oem.54.9.681 PMID:9423583

12. Attar SM. Frequency and risk factors of musculoskeletal pain in nurses at a tertiary center in Jeddah, Saudi Arabia: a cross sectional study. BMC Res Notes 2014 Jan 25;7(1):6. https://doi.org/10.1186/1756-0500-7-61 PMID:24460669

13. Sikiru L, Hanifa S. Prevalence and risk factors of low back pain among nurses in a typical Nigerian hospital. Afr Health Sci. 2010 Mar;10(1):26-30. PMID: 20811521

14. Tezel A. Musculoskeletal complaints among a group of Turkish nurses. Int J Neurosci 2005 Jun;115(6):871-80. https://doi. org/10.1080/00207450590897941 PMID:16019580

15. Lorusso A, Bruno S, L'Abbate N. A review of low back pain and musculoskeletal disorders among Italian nursing personnel. Ind Health. 2007 Oct;45(5):637-44. https://doi.org/10.2486/indhealth.45.637 PMID:18057806

16. Leggat PA, Smith DR, Clark MJ. Prevalence and correlates of low back pain among occupational therapy students in Northern Queensland. Can J Occup Ther. 2008 Feb;75(1):35-41. https://doi.org/10.2182/cjot.07.014 PMID:18323366

17. Smith DR, Wei N, Zhao L, Wang R-S. Musculoskeletal complaints and psychosocial risk factors among Chinese hospital nurses. Occup Med (Lond). 2004 Dec;54(8):579-82. https://doi.org/10.1093/occmed/kqh117 PMID:15576874

18. Vieira ER, Kumar S, Coury HJ, Narayan Y. Low back problems and possible improvements in nursing jobs. J Adv Nurs. 2006 Jul;55(1):79-89. https://doi.org/10.1111/j.1365-2648.2006.03877.x PMID:16768742 
19. Charbotel B, Systchenko B, Ladreyt JT, Bergeret A. Evaluation de la fréquence des troubles musculo-squelettiques dans une blanchisserie hospitalière. Arch Mal Prof. 2003 Apr;64(2):77-82.

20. Lallahom LB, Gharbi R, Hmida AB, Zakraoui L, Hafsa LB, Boularas M. La lombalgie en milieu hospitalier : enquête dans les principaux hôpitaux de Tunis ( $\mathrm{n}$ = 573). Arch Mal Prof. 1990;51:399-404.

21. Keriri HM. Prevalence and risk factors of low back pain among nurses in operating rooms, Taif, Saudi Arabia. J Med Sci Res. 2013;4(1):3-10.

22. Wynne-Jones G, Dunn KM, Main CJ. The impact of low back pain on work: a study in primary care consulters. Eur J Pain. 2008 Feb;12(2):180-8. https://doi.org/10.1016/j.ejpain.2007.04.006 PMID:17561421

23. Côté P, Baldwin ML, Johnson WG, Frank JW, Butler RJ. Patterns of sick-leave and health outcomes in injured workers with back pain. Eur Spine J. 2008 Apr;17(4):484-93. https://doi.org/10.1007/s00586-007-0577-6 PMID:18214554

24. Abolfotouh S, Mahmoud K, Faraj K, Moammer G, ElSayed A, Abolfotouh M. Prevalence, consequences and predictors of low back pain among nurses in a tertiary care setting. Int Orthop. 2015 Dec;39(12):2439-49. https://doi.org/10.1007/s00264-015-2900-X PMID:26189128

25. Karahan A, Kav S, Abbasoglu A, Dogan N. Low back pain: prevalence and associated risk factors among hospital staff. J Adv Nurs. 2009 Mar;65(3):516-24. https://doi.org/10.1111/j.1365-2648.2008.04905.x PMID:19222649

26. Sikiru L, Shmaila H. Prevalence and risk factors of low back pain among nurses in Africa: Nigerian and Ethiopian specialized hospitals survey study. East Afr J Public Health. 2009 Apr;6(1):22-5. https://doi.org/10.4314/eajph.v6i1.45737 PMID:20000059

27. Shiri R, Karppinen R, Leino-Arjas P, Solovieva S, Viikari-Juntura E. The association between obesity and low back pain: a meta-analysis. Am J Epidemiol. 2010 Jan 15;171(2):135-54. https://doi.org/10.1093/aje/kwp356 PMID:20007994

28. Rodacki ALF, Fowler NE. Provensi CLG, Rodacki CLN, Dezan VH. Body mass as a factor in stature change. Clin. Biomech. 2005 Oct;20(8):799-805. https://doi.org/10.1016/j.clinbiomech.2005.04.005 PMID:16005554

29. Sidhu A, Sidhu G, Jindal RC, Ajay B, Nishat S. Sociodemographic profile of low back pain - Shaharnpur spine. Pb J Orthop. 2008;8(1):12. 